\title{
CORRECTION
}

Open Access

\section{Correction to: Patients' usability of seven most used dry-powder inhalers in COPD}

Roberto W. Dal Negro ${ }^{*}$, Paola Turco $^{2}$ and Massimiliano Povero ${ }^{3}$

\section{Correction to: Multidiscip Respir Med (2019) 14:30}

https://doi.org/10.1186/s40248-019-0192-5

After publication of the Original research article [1] it was brought to our attention that the sentence at the bottom of the section entitled Discussion (pag 6 of 9, just below Fig. 4) must be corrected as follows:

"In real life, DPIs are highly prescribed in Italian COPD patients being their prescription usually independent of their known basic characteristics and technical differences, such as the different number of main actions required for their actuation ( 7 for Breezhaler, 4 for Turbohaler, and 3 for the remaining devices)," and their intrinsic resistance, ranging from $0.017 \mathrm{kPa} 0.5 \mathrm{~L} / \mathrm{min}$ to $0.039 \mathrm{kPa} 0.5 \mathrm{~L} / \mathrm{min}$ $[28,29]$.

\section{Author details}

${ }^{1}$ National Centre for Respiratory Pharmacoeconomics and

Pharmacoepidemiology, Verona, Italy. ${ }^{2}$ Research \& Clinical Governance,

Verona, Italy. ${ }^{3}$ AdRes Health Economics and Outcome Research, Torino, Italy.

Published online: 26 November 2019

\section{Reference}

1. Negro D, et al. Patients' usability of seven most used dry-powder inhalers in COPD. Multidiscip Respir Med. 2019;14:30. https://doi.org/10.1186/s40248019-0192-5.

\footnotetext{
* Correspondence: robertodalnegro@gmail.com

The original article can be found online at https://doi.org/10.1186/s40248-

019-0192-5

${ }^{1}$ National Centre for Respiratory Pharmacoeconomics and

Pharmacoepidemiology, Verona, Italy

Full list of author information is available at the end of the article
}

(c) The Author(s). 2019 Open Access This article is distributed under the terms of the Creative Commons Attribution 4.0 International License (http://creativecommons.org/licenses/by/4.0/), which permits unrestricted use, distribution, and reproduction in any medium, provided you give appropriate credit to the original author(s) and the source, provide a link to the Creative Commons license, and indicate if changes were made. The Creative Commons Public Domain Dedication waiver (http://creativecommons.org/publicdomain/zero/1.0/) applies to the data made available in this article, unless otherwise stated. 